\title{
DÜBLIN
}

Technological University Dublin

ARROW@TU Dublin

\section{Effects of Peeling Methods on the Quality of Ready-to-use Carrot Slices}

\author{
Catherine Barry-Ryan \\ Technological University Dublin, Catherine.Barryryan@tudublin.ie \\ David O'Beirne \\ University of Limerick, david.oberine@ul.ie
}

Follow this and additional works at: https://arrow.tudublin.ie/schfsehart

Part of the Food Science Commons, and the Plant Sciences Commons

\section{Recommended Citation}

Barry-Ryan, C., O'Beirne, D.:Effects of peeling methods on the quality of ready-to-use carrot slices.International Journal of Food Science and Technology, 35 (2), pp.243-254. doi:10.1046/ j.1365-2621.2000.00335.x

This Article is brought to you for free and open access by the School of Food Science and Environmental Health at ARROW@TU Dublin. It has been accepted for inclusion in Articles by an authorized administrator of ARROW@TU Dublin. For more information, please contact arrow.admin@tudublin.ie, aisling.coyne@tudublin.ie, gerard.connolly@tudublin.ie.

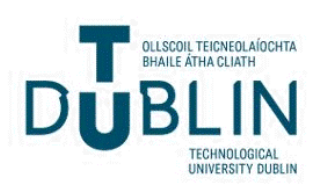




\title{
Effects of peeling methods on the quality of ready-to-use carrot slices International Journal of Food Science and Technology, 35, 243-254.
}

\author{
Catherine Barry-Ryan1 \& David O'Beirne2
}

\author{
1.School of Food Science and Environmental Health, Dublin Institute of Technology (DIT), Cathal \\ Brugha, Dublin 1, Ireland. catherine.barryryan@dit.ie. \\ 2. Dept of Life Sciences, University of Limerick, Limerick.
}

\begin{abstract}
Summary The effects of methods used for peeling and physiological age (over-wintering) on the quality and storage life of carrot disks packaged in modified atmosphere were examined. Commercial mechanical abrasion peeling using fine or coarse carborundum plates, was compared with carrots peeled by hand, before slicing into disks. Slices which had been peeled by abrasion had higher respiration rates, greater microbial contamination and growth rates, higher $\mathrm{pH}$ values, higher rates of weight loss and shorter microbiological shelf-lives than those which had been hand peeled. These results reflected the higher quality of the manually peeled carrots. Micrographs of the peeled surfaces confirmed that abrasion peeling inflicted greater damage. Carrots lifted in the autumn produced slices with longer shelf-lives than carrots lifted in the spring after over-wintering in the ground for four months.
\end{abstract}

Keywords

Abrasion peeling, damage, modified atmosphere storage, physiological age, shelf-life.

Introduction

The ready-to-use (RTU) carrots in this experiment were peeled, sliced into disks, packaged under modified atmospheres and shelf-stored at 8 8C. Deterioration in these products is generally attributed to microbial spoilage, changes in surface appearance and to physiological ageing (Brecht, 1980). Differences in rates of deterioration would result in differences in quality and storage life.

Peeling of root vegetables removes the epidermis and some sub-epidermal tissue. It bruises underlying tissue to varying degrees and leaves the new outer layer of cells damaged, causing leakage of cellular fluids which encourages microbial growth. Therefore, there are potential physiological, microbiological and physical implications of peeling. Some methods may accelerate the deterioration of minimally processed vegetables more than others. These effects may also be influenced by the physiological age of the carrots used.

Plant tissue responds to physical damage by an increase in its general metabolism, including respiration rate, and this response appears to be in proportion to the severity of the damage (Bolin et al., 1977; Bolin \& Huxsoll, 1991). Enzymatic reactions in cells damaged by peeling may cause offflavour or loss of firmness (Buckenhuskes \& Gierschner, 1990). The microflora responsible for the spoilage of ready-to-use vegetables include a large number of fungi, yeast and bacteria species (Manvell \& Ackland, 1986). Peeling of carrots could reduce the initial level of contamination by removing the outer layer (Garg et al., 1990), although methods such as abrasion peeling may lead to the reinoculation of micro-organisms into the damaged plant tissue, and extend any contamination from one root to many others.

As subsequent deterioration of the packaged RTU carrot disks may be affected by the severity or other features of the peeling method used, this paper compares the effects of hand, fine abrasion and 
coarse abrasion peeling, on their quality and storage life. It also looks at the effects of using carrots of different physiological ages by overwintering before lifting.

Materials and methods

Plant material

Locally grown carrots, cv. Nairobi, were used to produce modified atmosphere packaged carrot disks. All carrots were from the same grower and field near Thurles, Co. Tipperary (Avonmore Growers, Tipperary, Ireland). One batch of 'autumn-lifted' carrots were processed on the 3rd, 10th, 17th and 24th of October, during which time they were held at $48 \mathrm{C}$ in perforated plastic bags. 'Spring-lifted' carrots had been over-wintered in the ground and one batch was harvested for processing on the 6th, 13th, 20th and 27 th of March. The carrots had been washed by the producer. Medium sized roots (3]4 cm in diameter), free of defects were used.

Peeling and processing steps

All processing was done in a food processing unit under strict hygiene control. Carrots were either hand peeled using a Prestige hand-held peeler, peeling in one direction and removing a minimal amount of surface tissue or abrasion peeled using a Metcalfe electric abrasion peeler, Model 10 (Metcalfe Catering Equipment Ltd., Gwynedd, Wales, UK), using fine or coarse grain peeling plates. Carrots were then topped and tailed using a sharp knife, dipped for 5 min in chlorinated water (100 ppm adjusted to $\mathrm{pH} 6.9$, freshly prepared for each $5 \mathrm{~kg} \mathrm{lot}$ ) at $8 \mathrm{8C}$ and rinsed with distilled water. They were then drip-dried for 15 min in a perforated cage and cut into $6 \mathrm{~mm}$ thick disks using a Sammic CA300 food processor (Sammic, Barcelona, Spain). Disks were packaged in $350 \mathrm{~g}$ lots within $35 \mathrm{~m}$ thick oriented polypropylene (OPP, ICl, Dublin, Ireland) bags (280 $\times 180 \mathrm{~mm})$ and sealed in air with a Multivac A300 packaging machine (Multivac Packaging Machines, Wolfertschwenden, Germany). Although the recommended storage temperature for these products is 3]6 $8 \mathrm{C}$, ready-touse products are often found at higher temperatures in normal retail distribution (Carlin et al., 1990), and a storage temperature of $8 \mathrm{8C}$ was chosen for this investigation. Samples were evaluated during storage.

\section{Sensory evaluation}

Sensory evaluation was used to score appearance and aroma of the carrot disks prepared by different peeling methods. A panel of 10 judges, aged 22]30 years ( 8 female and 2 males, all members of the UL Food Science Research Centre) with sensory Evaluation experience, were trained in discriminative evaluation of carrot disks. The carrots used during the 12 training sessions, every Monday, Wednesday and Friday for 1 month, had been subjected to various storage treatments and times. Fresh hand peeled carrots were used as the control (score $=9$ ). During training the panel were shown the effects of storage over 10 days in air versus a range of modified atmospheres (achieved using different films). The effects of storage temperature $(3,8$ and $208 \mathrm{C}$ ) and time (10 days) on the carrot disks were also shown during the training sessions. The products were presented in groups, by sample day, to a single sensory judge at a time on a white laboratory bench in an odour-free fluorescent lit food laboratory. Assessment of the product by all ten judges was restricted to $1 \mathrm{~h}$ from opening the pack and packs were temporarily sealed between these evaluations. The products were coded with symbols to avoid bias. The products were scored for appearance and aroma, on a scale of 1]9, where $1=$ very poor, 4$] 5=$ fair and $9=$ excellent, on 1, 3, 6, 8 and 10 days after processing. A mean score of 5 or below was taken to indicate the end of shelf-life. Packs were analyzed in duplicate and each experiment had four replicates.

Respiration rate measurement

The effects different methods of peeling had on the respiration rate were monitored immediately after peeling using a purpose built respirometer (GowMac, Shannon, Republic of Ireland) (Barry-Ryan, 1996). The respirometer consisted of a large refrigerator, with fan assisted temperature control at $8{ }^{\circ} \mathrm{C}$, containing a cylinder of ethylene-free air. Air flow from the cylinder was controlled, humidified and subdivided into eight lines serving eight respiration chambers. Each respiration chamber consisted of a two-litre conical flask containing $350 \mathrm{~g}$ of the respiring product. The flasks were paired and each 
pair contained duplicate samples, with one pair left empty as air control. The conical flasks had gas tight rubber bung seals with tightly fitted stainless steel tubing to carry the air through each chamber at $12 \mathrm{~mL}$ $\min _{21}$. The outlet line from each chamber was automatically sampled $(1 \mathrm{~mL})$ hourly for $18 \mathrm{~h}$. Carbon dioxide $\left(\mathrm{CO}_{2}\right)$ and oxygen $\left(\mathrm{O}_{2}\right)$ levels were measured using a Gow-Mac gas chromatograph (Gow-Mac, Shannon, Republic of Ireland) fitted with a CTR1 column (Alltech, Illinois, USA) using helium (BOC, Limerick, Republic of Ireland) as a carrier gas. The respiration rate was calculated from the changes in the level of $\mathrm{CO}_{2}$ and $\mathrm{O}_{2}$ from the inlet gas to the outlet gas, once steady-state values were reached, generally obtained 2 to 3 hours after sealing. Each experiment had four replicates.

\section{Gas sampling of packs}

The gases within the shelf-stored packs were sampled throughout storage. Using an airtight syringe gas $10 \mathrm{~mL}$ was drawn from the pack through the $1 \mathrm{~mL}$ sample loop and analyzed as described for respiration rate. These packs were sampled in duplicate and the experiment repeated four times.

\section{Ultrastructural changes}

Carrot tissue for microscopic examination was prepared by 'free-hand sectioning'. Using a backed razor blade, thin $(, 12 \mathrm{~mm})$ sections from the freshly peeled surface were sliced in water, mounted in water and examined microscopically (Peacock \& Bradbury, 1973). Tissue samples were fixed using formyl acetic acid, prepared by adding $5 \mathrm{~mL}$ glacial acetic acid, and $85 \mathrm{~mL}$ of $70 \%$ ethyl alcohol, to $10 \mathrm{~mL}$ formaldehyde $(40 \%)$. Tissue ultrastructure was photographed using a compound Olympus microscope (BH2, Olympus, Hamburg, Germany), magnification 400, with an Olympus (PMG, Olympus, Hamburg, Germany) camera attachment.

Carrot tissue samples were examined for the presence of lignin by staining for $2 \mathrm{~min}$ in phloroglucinol. This stain was prepared by adding $5 \mathrm{~g}$ of phloroglucin to $100 \mathrm{~mL} 75 \%$ ethyl alcohol. The stain was removed by washing with concentrated hydrochloric acid for approximately $1 \mathrm{~min}$ or until a distinctive red colour appeared. The specimen was then washed with water and examined under the microscope. Phloroglucinol stains lignified cell walls red and can be used as a positive test for lignin (Fukuda \& Komamine , 1982).

\section{Weight loss}

A model sealed OPP package, with identical product : package ratio as the test package, containing four carrot slices lying flat was accurately weighed at regular intervals during storage to determine the rate of weight loss. Weighings were made with an accuracy of $\pm 1 \times 10^{-5} \mathrm{~g}$.

\section{Exudate production}

Exudate was measured by the method used by Carlin et al. (1990). A sample (4 g) was placed between two filter papers (Whatman No. $541,5 \mathrm{~cm}$ dia, Whatman, Kent, UK); a force of $10 \mathrm{~kg}$ was applied for $10 \mathrm{~s}$ and the filter papers were weighed again. This measurement was done in quadruplicate and there were four replicates of the experiment, values were expressed in $\mathrm{g}$ exudate $/ 100 \mathrm{~g}$ fresh weight.

\section{Microbial enumeration}

Packages from each treatment were sampled during storage after 1, 3, 6, 8 and 10 days. The product $(40 \mathrm{~g})$ was added to $360 \mathrm{~mL}$ sterile peptone water and blended (2 $\mathrm{min}$ ) at high speed in a sterile Warring Blender (Warring Products, New Hartford, USA). Serial dilutions $\left(10^{-1}\right.$ to $\left.10^{-6}\right)$ were made by using $1 \mathrm{~mL}$ of macerated sample with $9 \mathrm{~mL}$ of peptone water. The drop and spread technique was used with $0.1 \mathrm{~mL}$ of each dilution spread in duplicate using a sterile glass spreader. The media used were de Man, Rogasa and Sharpe (MRS) for lactic acid bacteria, plate count agar for total counts, violet red bile agar for coliforms and malt extract agar for yeasts and moulds. Media were prepared and incubated as directed by the manufacturer (Oxoid). Duplicate and control samples were prepared for each sample and only plates with counts of 30]300 colony forming units (cfu) were used. There were four replicates of the experiment.

Measurement of $\mathrm{pH}$

Disks (100 g) were blended for 2 min with $100 \mathrm{~mL}$ of distilled deionised water $(\mathrm{pH} 7)$ and the $\mathrm{pH}$ was 
measured with a CD300 digital $\mathrm{pH}$ meter (WPA, Saffron Walden, UK).

\section{Statistical analysis}

All the data collected were subjected to analysis of variance (ANOVA) and a least significant difference multicomparison test to determine significant differences between treatments (Shamaila et al., 1992).

Results and discussion

\section{Sensory scores}

From appearance and aroma scores the shelf-life for carrot discs was found to be $6-8$ days at $8{ }^{\circ} \mathrm{C}$. However, the shelf-life scores were always highest in the hand-peeled slices and lowest in those coarse abrasion peeled. Significant losses in appearance occurred at day 1 for autumn-lifted coarse abrasion peeled slices (Fig. 1a), and were greatest for both abrasion peeled carrots at day 3; a similar score loss was not reached in hand-peeled slices until day 6 . In these carrots aroma scores (Fig. 1b) were not significantly less $(P, 0.05)$ than in hand-peeled slices until day 6 . In the slices prepared from spring-lifted carrots all scores at day 1 (Fig. 1c, d) were slightly less than for autumn-lifted carrot slices, although the shelf-lives were similar. Only the appearance scores for hand-peeled slices remained significantly higher (Fig. 1c).

Deterioration in visual quality of carrots is generally believed to be as a result of the discolouration caused by production of lignin and 'drying out' of damaged cells (Bolin \& Huxsoll, 1991; Tatsumi et al., 1993). The sensory data presented here were supported by microscopic examination of the carrot surface tissue. The extent of disruption of cells and
Figure 1 Effects of peeling method on the appearance $(\mathrm{a}, \mathrm{c})$ and aroma (b, d) scores of OPP packaged carrot disks stored at $8{ }^{\circ} \mathrm{C}$ (closed symbols ] autumn-lifted carrots and open symbols ] stored carrots). Values are means for four determinations each done in duplicate, separated by Fisher's least significant difference $(P<0.05)$, denoted by different letters.
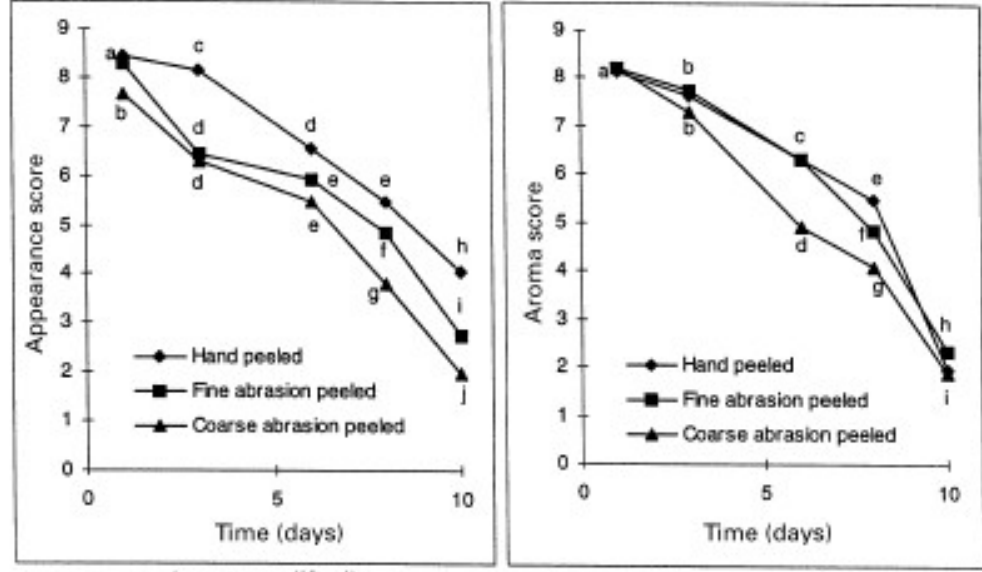

[a-autumn-lifted]

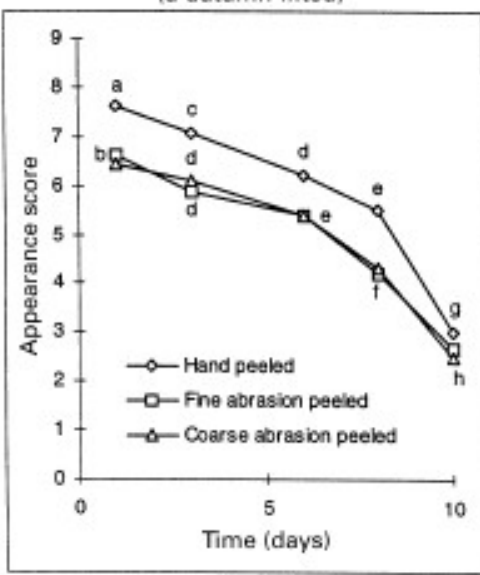

[c-spring-lifted]

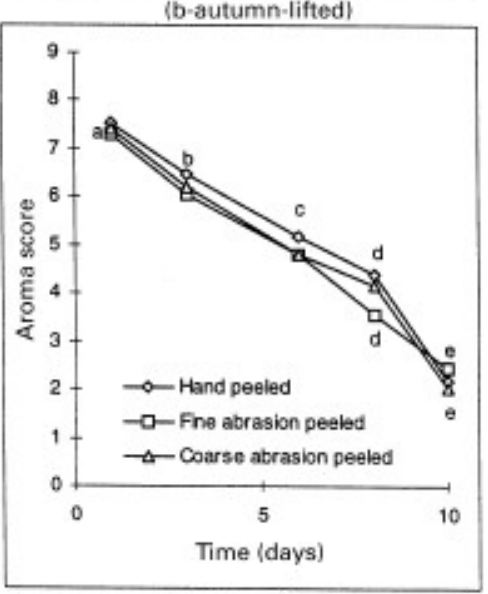

(d-spring-lifted) 
Figure 2 (a) The peeled surface of hand-peeled carrot disks, longitudinal section, after 1 day of storage in OPP bags at $8{ }^{\circ} \mathrm{C}(x 400)$ (b) The peeled tissue of hand-peeled carrot disks, longitudinal section, after 10 days of storage in OPP bags at $8{ }^{\circ} \mathrm{C}(\mathrm{x} 400)$.
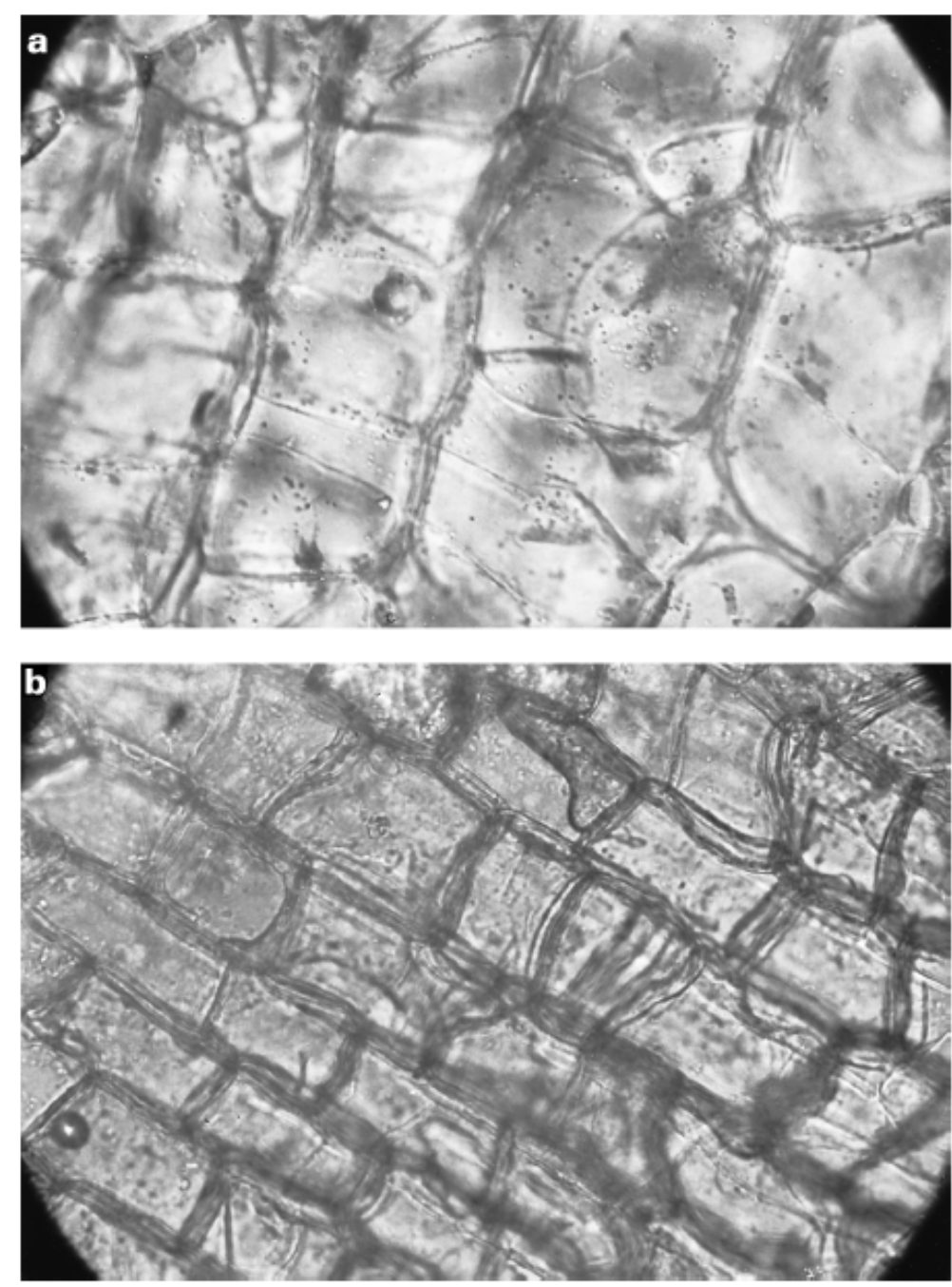

subsequent lignification were microscopically greater for the abrasion peeled products and this contributed to the decline in visual quality (Figs $2 a$ and $3 a$ ). Such microscopic differences in surface tissue related to the severity of processing have also been demonstrated in shredded lettuce (Bolin et al., 1977).

Initially, carrot disks prepared from autumn-lifted carrots had significantly higher appearance and aroma scores than those prepared from carrots which had been stored for 4 months. This may be owing to the higher microbial loads, combined with greater cell permeability and exudation of the spring-lifted products. The higher respiration rates (Table 1) and the greater weight loss over storage (Fig. 4) of carrot disks produced from the autumn-lifted vegetables also support these findings, as they indicate greater integrity and higher quality of the tissue. Coutre et al. (1993) also found that the scoring of minimally processed lettuce by a sensory panel varied greatly depending on the physiological age of the raw material used. Watada et al. (1979) and Kader et al. (1982) both showed that the quality of fresh and processed products was dependent on physiological age.

\section{Respiration rate}

Hand-peeling of whole carrots increased respiration rates from about $11 \mathrm{mLCO}_{2} / \mathrm{g} / \mathrm{h}$ to $13 \mathrm{mLCO}_{2} / \mathrm{g} / \mathrm{h}$ (Table 1). Slicing of these hand peeled carrots into 
Figure 3 (a) The peeled tissue of fine abrasion peeled carrot disks, longitudinal section, after 1 day of storage in OPP bags at $8{ }^{\circ} \mathrm{C}(x 400)$ (b) The peeled tissue of fine abrasion peeled carrot disks, longitudinal section, after 10 days of storage in OPP bags at $8^{\circ} \mathrm{C}(\mathrm{x} 400)$.
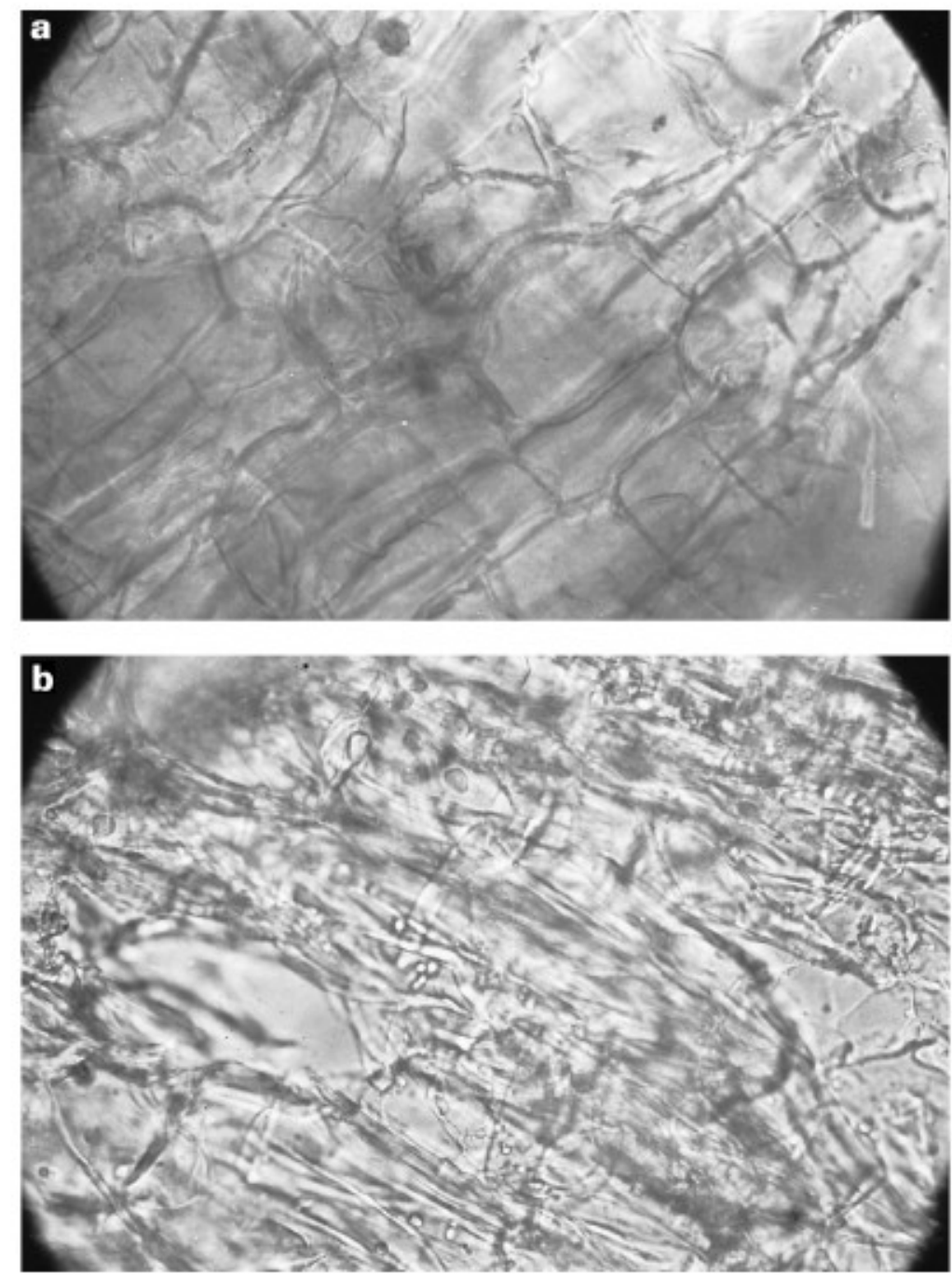

disks increased respiration on average by a further $18 \%$, to $15 \mathrm{mLCO}_{2} / \mathrm{g} / \mathrm{h}$. In the case of autumn-lifted carrots, fine abrasion peeling slightly increased respiration rate over that of hand peeled carrot disks and coarse abrasion peeling increased it further $(P<0.05$, Table 1).

By contrast, carrot disks prepared from hand peeled spring-lifted carrots respired at less than half the rate of their autumn-lifted equivalents. The effects of abrasion peeling on this material were far greater. Fine abrasion peeling increased respiration rates by $70 \%$ and coarse abrasion peeling increased them by $250 \%$ (Table 1) compared to that of the equivalent autumn-lifted coarse-peeled disks.

These peeling processes remove the epidermis and some associated sub-epidermal tissue from the carrot surface. The increases in respiration rates reported are owing to complex stress responses which include wound repair and synthesis of a new protective layer (Kahl \& Laties, 1989). Thus, Bolin \& Huxsoll (1991) have shown that abrasion peeled carrots developed white lignin-type material at their surfaces. These higher respiration rates may also contribute to more rapid physiological ageing and to accelerated quality deterioration owing to the consumption of sugars and other reserves (Crisosto et al., 1993). A decrease in sensory scores for these carrot disks was reflected in the increase in respiration rate.

The finding that respiration rates of carrot disks decreased with increasing physiological age is in line 
Table 1 Effects of peeling method on the respiration rates ${ }^{*}$ at $8{ }^{\circ} \mathrm{C}$ of carrot disks prepared by different peeling method from carrots of two physiological ages

\begin{tabular}{|c|c|c|}
\hline $\begin{array}{l}\text { Physiological age } \\
\text { Testing time }\end{array}$ & $\begin{array}{l}\text { Peeling } \\
\text { method }\end{array}$ & $\begin{array}{l}\text { Respiration rate } \\
\text { ( } \mu \mathrm{L} \mathrm{CO}_{2} \mathrm{~g}^{-1} \text { fresh weight) }\end{array}$ \\
\hline Autumn-lifted carrots & $\begin{array}{l}\text { Unpeeled } \\
\text { whole }\end{array}$ & $11.0 \mathrm{a}$ \\
\hline \multirow[t]{4}{*}{ Sept-Nov 1995} & $\begin{array}{l}\text { Hand-peeled } \\
\text { whole }\end{array}$ & $13.0 \mathrm{~b}$ \\
\hline & $\begin{array}{l}\text { Hand-peeled } \\
\text { slices }\end{array}$ & $15.5 \mathrm{c}$ \\
\hline & $\begin{array}{l}\text { Fine-abrasion } \\
\text { slices }\end{array}$ & $16.5 \mathrm{~d}$ \\
\hline & Coarse-abrasion & $17.7 \mathrm{e}$ \\
\hline $\begin{array}{l}\text { Spring-lifted carrots } \\
\text { (Over wintered }\end{array}$ & $\begin{array}{l}\text { Hand } \\
\text { peeled }\end{array}$ & $6.7 f$ \\
\hline for 4 months) & Fine & $11.5 \mathrm{a}$ \\
\hline \multirow[t]{2}{*}{ March-April 1996} & abrasion & \\
\hline & Coarse & $17.3 \mathrm{~g}$ \\
\hline
\end{tabular}

*Means separated by Fisher's least significant difference $(p<0.05)$. Data are the mean for three replications. For each physiological age means followed by a different letter are significantly different. with the work of Kader (1987). He reported that respiration rates are highest in immature and freshly harvested plant tissue and that these decline during storage.

The data presented are of practical commercial significance. Mild abrasion peeling caused smaller increases in respiration rates than coarse abrasion peeling; these increases were small in autumn-lifted carrots but very substantial in spring-lifted carrots.

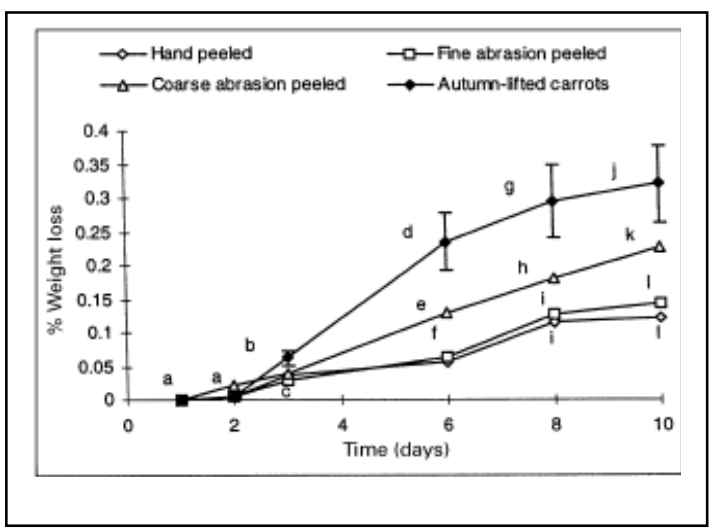

Figure 4 Effects of peeling method on weight loss of carrot disks during storage at $8{ }^{\circ} \mathrm{C}$. Values are means for four determinations each done in duplicate, separated by Fisher's least significant difference $(P<0.05)$, denoted by different letters.

\section{Gas analysis of packs}

The atmosphere modification was slower $(p,<0.05)$ for carrot disks prepared by hand peeling than those abrasion peeled (autumn-lifted carrots, Fig. 5a). This trend was in line with the respiration rate data. The level of $\mathrm{O}_{2}$ in all three packs had fallen to 1$] 1.5 \%$ by day 6 and remained at this level for the rest of storage. The final range of $\mathrm{CO}_{2}$ levels in packs containing the abrasion peeled carrot disks was $30] 35 \%$, and $25 \%$ in packs containing the hand peeled products (Fig. $5 \mathrm{a}$ ).

The gas levels within the packs containing disks prepared from spring-lifted carrots, did not reflect the large differences in respiration rates (measured for $24 \mathrm{~h}$ following processing) owing to the peeling method. By day 6 an equilibrium level of $1.5 \% \mathrm{O}_{2}$ was reached in all packs (Fig. 5b), limited by the OPP film permeability to $\mathrm{O}_{2}$ $\left(1,200 \mathrm{~mL} \cdot \mathrm{m}^{2}\right.$.day $\left.{ }^{1} \cdot \mathrm{atm}^{1}\right)$. The levels of $\mathrm{CO}_{2}$ within these packs continued to rise rapidly, which may imply anaerobiosis.

The final $\mathrm{CO}_{2}$ levels were significantly higher in packs containing disks prepared from spring-lifted carrots than those from the autumn-lifted carrots, even though their initial respiration rates were significantly lower (Table 1). This may also be explained by more active anaerobiosis in the packs 
Figure 5 Effects of peeling method on levels of $\mathrm{CO}_{2}$ (open symbols) and $\mathrm{O}_{2}$ (closed symbols) in the atmospheres of OPP packs containing carrot disks, produced from (a) autumn-lifted carrots and

(b) stored carrots peeled by different methods, during storage $\left(8^{\circ} \mathrm{C}\right)$. Values are means for four determinations each done in duplicate, separated by Fisher's least significant difference $(P<0.05)$ denoted by different letters.

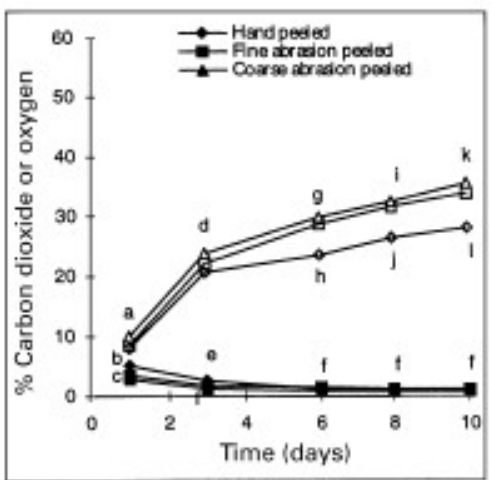

(a-autumn-lifted)

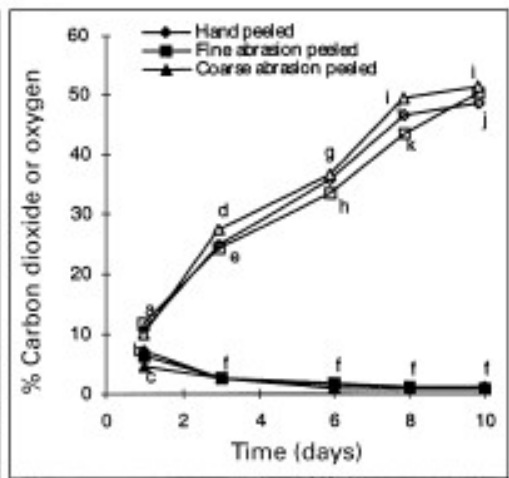

(b-spring-lifted) containing the spring-lifted carrots. The respiration rate of the autumn-lifted carrots appears to have stabilized as the rate of increase in $\mathrm{CO}_{2}$ levels slows significantly after day 3 .

The levels of $\mathrm{CO}_{2}$ and $\mathrm{O}_{2}$ within the packs are very important, as an equilibrium modified atmosphere of $1] 5 \% \mathrm{O}_{2}$ and 5$] 15 \% \mathrm{CO}_{2}$ is desirable (Brecht, 1980). The rate of development of this modified atmosphere is also important, because, such modified atmospheres reduce spoilage by aerobic mesophiles (Carlin et al., 1990). Also, owing to the decreased availability of oxygen many $\mathrm{O}_{2}$ requiring enzymatic reactions may be reduced, such as respiration (O'Beirne, 1990). From day $6 \mathrm{CO}_{2}$ levels in all packs were very high and this may result in $\mathrm{CO}_{2}$ injury, accelerating flavour and membrane damage. This was reflected in the appearance scores which fell below 5 , implying the end of shelf-life, by day 8 for the abrasion peeled slices. of these cells retaining their regular shape. After one day of storage the cell walls of the abrasion peeled carrots had already started to thicken, and the rough surface created by the carborundum plate can be seen. After ten days of storage the cell walls had thickened substantially and 'drying out' effects can be seen in the cracking of the outer layer of abrasion peeled carrot tissue (Fig. 3b). There is also evidence of lignification (positive red colour after staining with phloroglucinol) which increased in intensity over storage (data not shown). The surface of this tissue is littered with cell debris and can be compared with Fig. $2 \mathrm{~b}$ which, owing to the mild processing treatment is free of cell debris.

The extent of disruption of cells and subsequent lignification were clearly greater for the abrasion peeled products and this contributed to the decline in appearance scores. This decline in appearance scores was mainly as a result of drying out and whitening of the carrot surface. Such microscopic differences in surface tissue related to severity of processing have also been demonstrated in shredded lettuce (Bolin et al., 1977).

Weight loss

In spring-lifted carrots, weight loss from coarse abrasion peeling was significantly higher (two-fold) than from the other peeling treatments (Fig. 4). There were no significant differences in weight loss from disks prepared from hand or fine abrasion peeled carrots.

Peeling method had no significant effects on weight loss from disks prepared from autumn-lifted carrots (Fig. 4 ] closed symbols). Weight loss by 
carrot disks prepared from the spring-lifted carrots was lower than that from the autumn-lifted carrots.

This weight loss involves drying out of the processed carrot tissue and loss of this water vapour through the permeable packaging film. The findings followed similar trends to those observed by Izumi \& Watada (1994) for shredded carrots and Roy et al. (1995) for modified atmosphere packaged mushrooms. Deterioration in quality (reduced appearance scores) was attributed partly to this drying-out and thus was related to the severity of peeling treatment. Packs containing carrot disks prepared using the autumn-lifted carrots lost the most weight. This may be as a result of the greater cell integrity of the autumn-lifted vegetables and the higher initial turgidity of this tissue. Thus, there may have been a greater amount of intracellular water available for evaporation than when spring-lifted vegetables were used for processing. The measurement of the total pack weight loss is essential, as once opened the tissue rapidly loses surface moisture, making moisture content measurements impossible.

Microbial enumeration

There were no significant differences between the initial counts of total aerobes and initial loads of coliforms on disks prepared from hand or fine abrasion peeled autumn-lifted carrots (Table 2). Hand peeling produced disks with the lowest initial loads of lactic acid bacteria, when compared to abrasion peeled products. Carrot disks prepared by hand peeling had the lowest loads of total aerobes, coliforms and lactic acid bacteria for the rest of storage. Disks prepared from coarse abrasion peeled carrots had the highest loads initially, but after day 3 there was no significant difference between the two abrasion peeled products. On day 1 of storage there were no differences in the loads of yeasts and moulds on the products peeled differently. By day 3 , the loads of yeasts and moulds on the abrasion peeled products had risen above that of the hand peeled products. But, on days 6 to 8 there were no differences between the yeast and mould loads on hand and fine abrasion peeled products.

For the spring-lifted carrots, similar microbial load trends to those on the disks prepared from autumnlifted carrots were found (Table 3), but with significantly higher loads. The initial loads were ,2 Log units higher than those on the autumn-lifted
Table 2 Effects of peeling method $\mathrm{m}$ micrabiel counts* of shelf-stored MA packaged carrot diks, prepared from autumnhifled raw material $\left(8^{\circ} \mathrm{C}\right)$

\begin{tabular}{|c|c|c|c|c|c|}
\hline \multirow{2}{*}{$\begin{array}{l}\text { Time } \\
\text { (Days) }\end{array}$} & \multirow{2}{*}{$\begin{array}{l}\text { Storage } \\
\text { Method }\end{array}$} & \multicolumn{4}{|l|}{$\log _{1} / g$} \\
\hline & & $\begin{array}{l}\text { Pooling } \\
\text { TAC }\end{array}$ & Califorms & LAB & $\begin{array}{l}\text { Yeasts } \\
\text { \& Moulds }\end{array}$ \\
\hline \multirow[t]{3}{*}{1} & $\begin{array}{l}\text { Hand } \\
\text { paalad }\end{array}$ & $4.5 \mathrm{a}$ & $4.4 a$ & $3.3 \mathrm{a}$ & $5.3 \mathrm{a}$ \\
\hline & $\begin{array}{l}\text { Fine } \\
\text { abrasion }\end{array}$ & $4.8 \mathrm{a}$ & $4.7 \mathrm{a}, \mathrm{b}$ & $4.1 \mathrm{~b}$ & $5.4 \mathrm{a}$ \\
\hline & $\begin{array}{l}\text { Coarse } \\
\text { abrasion }\end{array}$ & $5.6 \mathrm{~b}$ & $5 b$ & $4.4 \mathrm{~b}$ & $5.5 \mathrm{a}$ \\
\hline \multirow[t]{3}{*}{3} & $\begin{array}{l}\text { Hand } \\
\text { paalad }\end{array}$ & $5.9 \mathrm{a}$ & $6 \mathrm{a}$ & $5 a$ & $6.7 \mathrm{a}$ \\
\hline & $\begin{array}{l}\text { Fine } \\
\text { abrasion }\end{array}$ & $6.3 \mathrm{~b}$ & $6.3 \mathrm{~b}$ & $5.2 \mathrm{~b}$ & $7.4 b$ \\
\hline & $\begin{array}{l}\text { Coarse } \\
\text { abrasion }\end{array}$ & 6.70 & 6.60 & 5.70 & $7.5 b$ \\
\hline \multirow[t]{3}{*}{6} & $\begin{array}{l}\text { Hand } \\
\text { paelad }\end{array}$ & $6.6 \mathrm{a}$ & $6.2 \mathrm{a}$ & $5.6 \mathrm{a}$ & $7.1 \mathrm{a}$ \\
\hline & $\begin{array}{l}\text { Fine } \\
\text { abrasion }\end{array}$ & $7.1 \mathrm{~b}$ & $6.8 \mathrm{~b}$ & 6. $1 \mathrm{~b}$ & $7.4 \mathrm{a}, \mathrm{b}$ \\
\hline & $\begin{array}{l}\text { Coarse } \\
\text { abrasion }\end{array}$ & $7.7 \mathrm{~b}$ & $7.4 \mathrm{~b}$ & 6. $4 \mathrm{~b}$ & $8 \mathrm{~b}$ \\
\hline \multirow[t]{3}{*}{8} & $\begin{array}{l}\text { Hand } \\
\text { pealad }\end{array}$ & $7.4 \mathrm{a}$ & $7.2 \mathrm{a}$ & 6.1a & $7.5 \mathrm{a}$ \\
\hline & $\begin{array}{l}\text { Fine } \\
\text { abrasion }\end{array}$ & $7.9 b$ & $7.9 \mathrm{~b}$ & $6.3 \mathrm{a}$ & $7.6 \mathrm{a}$ \\
\hline & $\begin{array}{l}\text { Coarse } \\
\text { abrasion }\end{array}$ & $8.2 b$ & $8.2 b$ & $6.7 \mathrm{a}$ & $\mathrm{gb}$ \\
\hline 10 & $\begin{array}{l}\text { Hand } \\
\text { paalad }\end{array}$ & 8.1a & $7.1 \mathrm{a}$ & 7.49 & $7.8 \mathrm{a}$ \\
\hline \multirow[t]{2}{*}{ * } & $\begin{array}{l}\text { Fine } \\
\text { abrasion }\end{array}$ & $7.8 \mathrm{a}$ & $\mathrm{ab}$ & 8. $1 \mathrm{~b}$ & $8.2 b$ \\
\hline & $\begin{array}{l}\text { Coarse } \\
\text { abrasion }\end{array}$ & $8.5 b$ & $8.3 \mathrm{~b}$ & 8. $4 \mathrm{~b}$ & 8.70 \\
\hline
\end{tabular}

carrots. Although the microbial growth rates were not as high in the products prepared from spring-lifted carrots, the final loads were still significantly higher than for autumn-lifted carrot products. 
Table 3 Effects of peeling method on microbial counts* of shelf-stored MA packaged carrot disks, prepared from springlifted carrots $\left(8{ }^{\circ} \mathrm{C}\right)$

\begin{tabular}{|c|c|c|c|c|c|}
\hline \multirow{2}{*}{$\begin{array}{l}\text { Time } \\
\text { (Days) }\end{array}$} & \multirow{2}{*}{$\begin{array}{l}\text { Storage } \\
\text { Method }\end{array}$} & \multicolumn{4}{|l|}{$\log _{10} / g$} \\
\hline & & $\begin{array}{l}\text { Peeling } \\
\text { TAC }\end{array}$ & Coliforms & LAB & $\begin{array}{l}\text { Yeasts } \\
\text { \& Moulds }\end{array}$ \\
\hline \multirow[t]{3}{*}{1} & $\begin{array}{l}\text { Hand } \\
\text { peeled }\end{array}$ & $6.3 a$ & $6.6 \mathrm{a}$ & $5.8 a$ & $6.4 \mathrm{a}$ \\
\hline & $\begin{array}{l}\text { Fine } \\
\text { abrasion }\end{array}$ & $6.6 \mathrm{~b}$ & $7.3 b$ & $5.9 \mathrm{a}$ & $6.5 a$ \\
\hline & $\begin{array}{l}\text { Coarse } \\
\text { abrasion }\end{array}$ & $8.1 \mathrm{c}$ & $7.2 \mathrm{~b}$ & $5.8 \mathrm{a}$ & $6.7 b$ \\
\hline \multirow[t]{3}{*}{3} & $\begin{array}{l}\text { Hand } \\
\text { peeled }\end{array}$ & $7.7 \mathrm{a}$ & $7.2 \mathrm{a}$ & $7.3 \mathrm{a}$ & $7.7 \mathrm{a}$ \\
\hline & $\begin{array}{l}\text { Fine } \\
\text { abrasion }\end{array}$ & $8.1 b$ & $8.1 b$ & $7.8 \mathrm{~b}$ & $8.3 b$ \\
\hline & $\begin{array}{l}\text { Coarse } \\
\text { abrasion }\end{array}$ & $8.3 b$ & $8.5 \mathrm{c}$ & $7.8 \mathrm{~b}$ & $8.4 \mathrm{~b}$ \\
\hline \multirow[t]{3}{*}{6} & $\begin{array}{l}\text { Hand } \\
\text { peeled }\end{array}$ & $8.6 a$ & $8.3 \mathrm{a}$ & $8.4 \mathrm{a}$ & $8.7 \mathrm{a}$ \\
\hline & $\begin{array}{l}\text { Fine } \\
\text { abrasion }\end{array}$ & $9.1 \mathrm{~b}$ & $8.8 b$ & $8.5 a$ & $8.9 a$ \\
\hline & $\begin{array}{l}\text { Coarse } \\
\text { abrasion }\end{array}$ & $9.4 \mathrm{c}$ & $9 b$ & $8.8 \mathrm{~b}$ & $9.1 \mathrm{~b}$ \\
\hline \multirow[t]{3}{*}{8} & $\begin{array}{l}\text { Hand } \\
\text { peeled }\end{array}$ & $10 \mathrm{a}$ & $8.7 a$ & $9.2 \mathrm{a}$ & $9.2 \mathrm{a}$ \\
\hline & $\begin{array}{l}\text { Fine } \\
\text { abrasion }\end{array}$ & $10.4 \mathrm{~b}$ & $9 b$ & $9.2 \mathrm{a}$ & $9.5 \mathrm{~b}$ \\
\hline & $\begin{array}{l}\text { Coarse } \\
\text { abrasion }\end{array}$ & $10.4 \mathrm{~b}$ & $9.4 \mathrm{c}$ & $9.6 \mathrm{~b}$ & $9.8 \mathrm{c}$ \\
\hline \multirow[t]{3}{*}{10} & $\begin{array}{l}\text { Hand } \\
\text { peeled }\end{array}$ & $10.4 \mathrm{a}$ & $9.2 \mathrm{a}$ & $9.7 \mathrm{a}$ & $9.7 \mathrm{a}$ \\
\hline & $\begin{array}{l}\text { Fine } \\
\text { abrasion }\end{array}$ & $10.2 \mathrm{a}$ & $9.7 b$ & $9.6 \mathrm{a}$ & $10.1 \mathrm{~b}$ \\
\hline & $\begin{array}{l}\text { Coarse } \\
\text { abrasion }\end{array}$ & $10.3 \mathrm{a}$ & $9.9 \mathrm{~b}$ & $9.6 \mathrm{a}$ & $10.6 \mathrm{~b}$ \\
\hline
\end{tabular}

Number of viable micro-organisms detected ( $\log 10$ per gram) and means (for eigh determinations) separated by Fisher's least significant difference $(P<0.05)$. Means the individual storage times and within columns with different letters are significantly different at $\mathrm{P}<0.05$.

Microbial load is an important index of quality as storage life of minimally processed carrot disks is terminated by microbial growth, spoilage becoming apparent at 107]108 micro-organisms per gram (product aroma). Microbial growth was reflected in a decline in the aroma scores of carrot disk products. As would be expected, RTU vegetable products are more susceptible to microbial spoilage than whole vegetables (Carlin et al., 1989). A survey carried out by Garg et al. in 1990, found similar numbers and types of micro-organisms on commercial packs of carrot sticks to those reported here. Koek et al. (1983) also reported similar population sizes and types of micro-organisms on carrots. Generally, disks prepared from hand peeled carrots had the lowest microbial loads and therefore had longer shelf-lives. This may be owing to decontamination by this peeling method, in the removal of the outer layer and large numbers of the epithelial microflora. The type of abrasion plate used also had significant effects on microbial loads, with disks from the coarse abrasion peeled carrots having higher growth rates than those prepared from fine abrasion peeled carrots. This may be due to the fact that abrasion peeling inoculated microbes deeper into the vegetable tissue, perhaps even protecting them from the chlorinated washing solution. Abrasion peeling also caused considerable cellular damage, releasing large quantities of nutrients which supported microbial growth. These effects were amplified by the harsher abrasion peeling method.

Initial contamination loads and their growth rates depended on the micro-organisms examined and the physiological age of the raw material. Significantly higher loads were observed when spring-lifted carrots were used, and this may have been owing to higher contamination or to an increase in the susceptibility of the tissue to microbial growth with increasing physiological age. The higher levels of exudate (Fig. 6) for the older tissue suggests poorer cell integrity and this probably promoted microbial

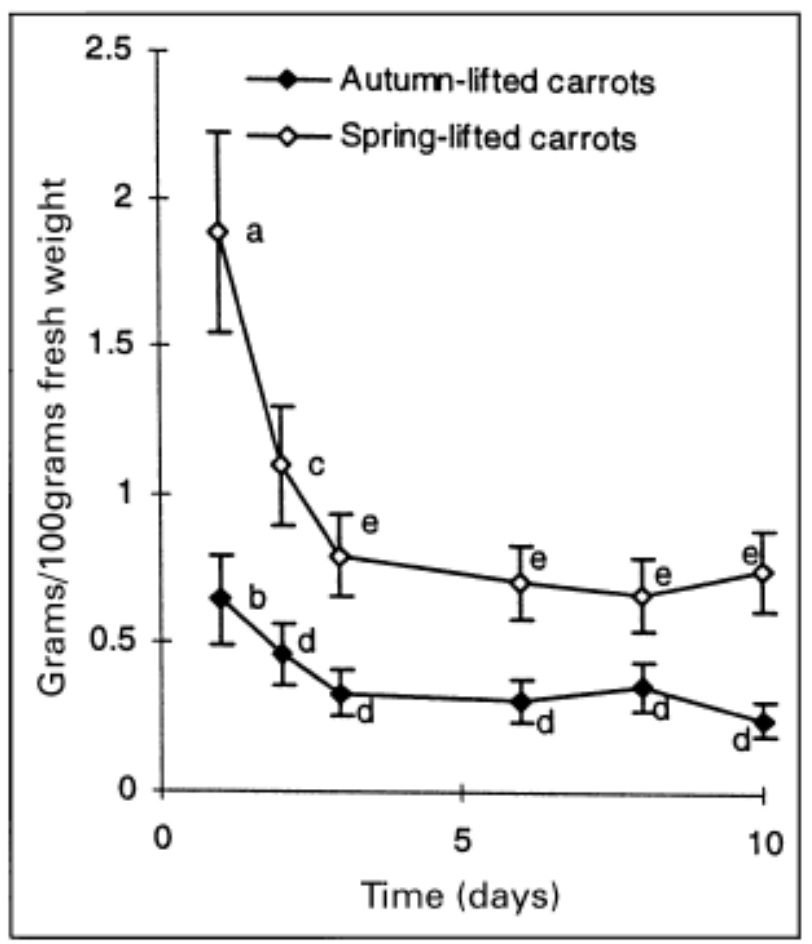

Figure 6 Effects of peeling method on exudate production by OPP packaged carrot disks stored at $80 \mathrm{C}$. Values are means for

twenty-four determinations (bars show range), separated by Fisher's least significant difference $(P<0.05)$, denoted by different letters. 
spoilage by providing more substrates. Although the growth rates were not as high, the final loads were still significantly higher than for autumn-lifted carrots for all isolations. Thus, for the spring-lifted carrots, the effects of peeling treatments were camouflaged by the significantly larger effect of physiological age on microbial loads. This increase in microbial loads with increasing physiological age is supported by findings by Babic et al. (1992), who found that total aerobic counts and yeast and mould counts increased with increasing physiological age of carrots used in the production of shredded carrots.

Tissue $\mathrm{pH}$

The $\mathrm{pH}$ values increased up to day 8, after which they began to fall for all samples (Fig. 7). There was a significant, though small, effect of peeling method on tissue $\mathrm{pH}$. Hand peeled carrots had lower $\mathrm{pH}$ values than abrasion peeled products throughout storage. For most of the storage period there were no significant differences between the $\mathrm{pH}$ of the abrasion peeled products. This $\mathrm{pH}$ increase coincided with increased microbial loads, which may have consumed organic acids and thus reduced acidity. King et al. (1991) also found that $\mathrm{pH}$ increased over the 15 days of storage of partially processed lettuce with increased microbial loads.

In summary, the method of peeling had significant

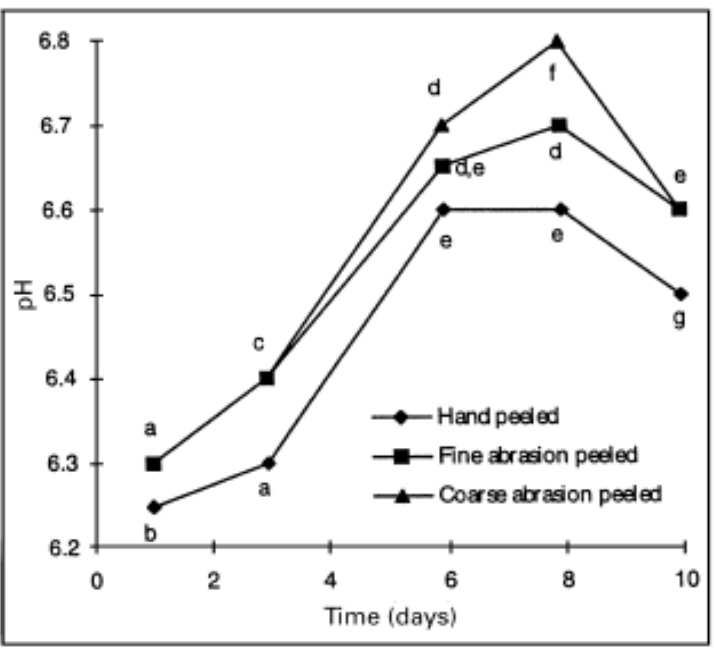

Figure 7 Effects of peeling method on $\mathrm{pH}$ during storage at $8{ }^{\circ} \mathrm{C}$. Values are means for four determinations done in duplicate, separated by Fisher's least significant difference $(P<0.05)$, denoted by different letters. effects on the quality and storage-life of modified atmosphere packaged ready-to-use carrot disks. These effects on quality appear to be caused through differences in the extent of surface damage, microbiological contamination and differences in the physiological response to damage (respiration rate and lignification). Loss of visual quality occurred through surface drying and suberisation of damaged tissue. The extent of microbial growth appears to be the major factor in the decline of aroma scores. Hand peeling resulted in the highest sensory scores. Although from the commercial standpoint hand peeling of root vegetables is not cost effective, it is a reference method against which commercial processing can be evaluated. In addition, there were important differences between commercially used peeling methods. The magnitude of these effects were dependent on the physiological age of the raw material used. Carrot disks produced from autumnlifted carrots were of higher quality and received higher sensory scores from day 1 and throughout storage, than those prepared using spring-lifted carrots. This appears to be owing to the higher microbial contamination and growth rates recorded on the physiologically older tissue which, in turn, are partly a consequence of the higher cell permeability and exudate levels.

\section{References}

Babic, I., Hilbert, G., Nguyen-the, C. \& Guirand, J. (1992). The yeast flora of stored ready-to-use carrots and their role in spoilage. International Journal of Food Science and Technology, 27, 473]484.

Barry-Ryan, C. (1996). Factors in deterioration of vegetables processed using novel mild techniques. PhD Thesis, University of Limerick, Ireland.

Bolin, H.R. \& Huxsoll, C.C. (1991). Control of minimally processed carrot (Daucus carota) surface discolouration caused by abrasion peeling. Journal of Food Science, 56, $416] 418$.

Bolin, H.R., Stafford, A.E., King, A.D. Jr \& Huxsoll, C.C. (1977). Factors affecting the storage stability of shredded lettuce. Journal of Food Science, 42, 1319]1321.

Brecht, P.E. (1980). Use of controlled atmospheres to retard deterioration of produce. Food Technology, 34, 45]50.

Buckenhuskes, H. \& Gierschner, K. (1990). Manufacture of delicatessen salads: special requirements for fruits and vegetables. Fleischwirtsch, 70, 1044]1047.

Carlin, F., Nguyen-the, C. \& Chambroy, Y. (1990). Effects of controlled atmospheres on microbial spoilage, electrolyte leakage and sugar content of fresh 'ready-to-use' grated carrots. International Journal of Food Science and Technology, 25, 110]119. 
Carlin, F., Nguyen-the, C., Cudennec, P. \& Reich, M. (1989). Microbiological spoilage of ready-to-use grated carrots. Science Des Aliments, 9, 371]386.

Coutre, R., Cantwell, M.I., Ke, D. \& Saltveit, M.E. Jr (1993). Physiological attributes related to quality attributes and storage-life of minimally processed lettuce. Horticultural Science, 28, 723]725.

Crisosto, C.H., Garner, D., Doyle, J. \& Day, K.R. (1993). Relationship between fruit respiration, brusing susceptibility, and temperature in sweet cherries. Horticultural Science, 28, 132]135.

Fukuda, H. \& Komamine, A. (1982). Lignin synthesis and its related enzymes as markers of tracheary-element differentiation in single cells isolated from the mesophyll of Zinnia elegans. Planta, 155, 423]430.

Garg, N., Churey, J.J. \& Splittoesser, D.F. (1990). Effect of processing conditions on the microflora of fresh-cut vegetables. Journal of Food Protection, 53, 701]703.

Izumi, H. \& Watada, A.E. (1994). Calcium treatments affect storage quality of shredded carrots. Journal of Food Science, 59, 106]109.

Kader, A.A. (1987). Respiration and gas exchange of vegetables. In: Postharvest Physiology of Vegetables (edited byJ. Weichmann). Pp. 25]43. New York: Marcel Decker.

Kader, A.A., Heinta, C.M. \& Chorads, A. (1982). Postharvest quality of fresh and canned clingstone peaches as influenced by genotype and maturity at harvest. Journal of the American Society of Horticultural Science, 107, 947]951.

Kahl, G. \& Laties, G.G. (1989). Ethylene-induced respiration in thin slices of carrot root. Journal of Plant Physiology, 134, 496]503.

King, A.D., Jr, Magnuson, J.A., Torok, T. \& Goodman, N.
(1991). Microbial flora and spoilage of partially processed lettuce. Journal of Food Science, 56, 459]461.

Koek, P.L., de Whitte, Y. \& de Maaker, J. (1983). The microbial ecology of prepared raw vegetables. In: Food Microbiology: Advances and Prospects (edited byT. A. Roberts \& F. A. Skinner). Pp. 231]239. London: Academic Press.

Manvell, P.M. \& Ackland, M.R. (1986). Rapid detection of microbial growth in vegetable salads at chill and abuse temperatures. Food Microbiology, 3, 59]65.

O'Beirne, D. (1990). MAP of fruits and vegetables. In: Chilled Foods: the State of the Art (edited by T. R. Gromley). Pp. 183]191. Amsterdam: Elsevier Applied Science.

Peacock, P. \& Bradbury, S. (1973). Microtechnical processes ] principles and techniques. In: Peacock's Elementary Microtechnique (edited by S. Bradbury). Pp. 33]49. 4th edn. London: Edward Arnold Publishers.

Roy, S., Anantheswaran, R.C. \& Beelman, R.B. (1995). Fresh mushroom quality as affected by modified atmosphere packaging. Journal of Food Science, 60, 334]340.

Shamaila, M., Powrie, W.D. \& Skura, B.J. (1992). Sensory evaluation of strawberry fruit stored under modified atmosphere packaging (MAP) by quantitative descriptive analysis. Journal of Food Science, 57, 1168]1172 and 1184.

Tatsumi, Y., Watada, A.E. \& Ling, P.P. (1993). Sodium chloride treatment or waterjet slicing effects on white tissue development of carrot sticks. Journal of Food Science, 58, $1390] 1392$.

Watada, A.E., Anderson, R.E. \& Aulenbach, B.B. (1979). Sensory, compositional and volatile attributes of controlled atmosphere stored peaches. Journal of the American Society of Horticultural Science, 104, 626]629. 